УДК 619:614.31:637.564:616.995

(C) 2015

Гавриленко О. С., кандидат ветеринарних наук, Хоміцька О. А., завідувач сектору мікробіологічних випробувань, Загорулько О. В., стариий науковий співробітник

Український державний науково-дослідний інститут нанобіотехнологій та ресурсозбереження

\title{
ВИЗНАЧЕННЯ МІКРОБІОЛОГІЧНИХ РИЗИКІВ ПІД ЧАС ДОСЛІДЖЕННЯ М'ЯСА СВИНЕЙ, УРАЖЕНИХ САРКОЦИСТОЗОМ
}

\section{Рецензент - кандидат ветеринарних наук М. С. Карпуленко}

У статті визначено підходи до оцінки мікробіологічних ризиків під час використання в їжу свинини, отриманої від уражених саркоцистозом тварин. Проведено аналіз мікробіологічного ризику м'яса свиней, уражених саркоцистозом, включено кількісну та якісну інформачію мікробіологічних небезпек у дослідженому матеріалі. Встановлено, щзо в зразках з різним ступенем ураження саркоцистами підвищується не тільки кількість мезофільних аеробних $i$ факультативно анаеробних мікроорганізмів (МАФАМ) у м'ясі, але й кількість патогенних і умовно-патогенних мікроорганізмів.

Ключові слова: мікробіологічний ризик, свинина, саркоцистоз, ступінь ураження.

Постановка проблеми. Проблема екологічної безпеки продуктів харчування завжди буде одним із найважливіших факторів, що впливає на стан здоров'я людини. Харчові продукти повинні задовольняти фізіологічні потреби людини в необхідних кількостях поживних речовин (білків, жирів, углеводів та комплексу вітамінів), відповідати встановленим вимогам згідно $з$ нормативними документами за вмістом речовин і фізичних чинників, які можуть становити небезпеку для здоров'я і життя людини [11]. За характером і ступенем небезпеки для здоров'я людини перше місце займає контамінація харчових продуктів мікрофлорою навколишнього середовища $[1,6]$.

Аналіз основних досліджень і публікацій, у яких започатковано розв'язання проблеми. Санітарна безпека та якість м'яса залежить від багатьох факторів, а саме: місця вигодовування тварин, від якості кормів, наявності ветеринарних препаратів, санітарного стану обладнання на підприємствах [1]. Забруднення бактеріями кормів, території та обладнання становить небезпеку для здоров'я людини. Патогенні та умовнопатогенні мікроорганізми потрапляють на продукт упродовж усього виробничого циклу. Тому вивчення мікробіологічної безпечності м'яса, яке реалізовується в роздрібній мережі, є важливим завданням сьогодення $[8,9]$.

Сучасна система ведення тваринництва ство- рила низку несприятливих умов (скупченість, гіподинамію, порушення газообміну, терморегуляції та мікроклімату), в цілому збільшують навантаження різного характеру на організм тварин. Встановлено, що під час адаптації тварини до середовища відбуваються значні функціональні перебудови в організмі на клітинному рівні, що нерідко призводить не тільки до зниження продуктивності, а й ослаблення резистентності їх організму до різних захворювань. Зараженість сільськогосподарських тварин саркоцистами в цих умовах різко зростає, а це у свою чергу сприяє збільшенню різних видів бактерій. Інфікування тварин саркоцистами має повсюдне поширення і приносить суттєвий економічний збиток сільському господарству, який виражається різким зниженням якості м'яса (містить більше вологи, вільних амінокислот, бідніший глікогеном, частіше інфіковане мікрофлорою, його фізико-хімічні показники гірші в порівнянні 3 нормативами і воно швидше піддається псуванню під час зберігання) [6, 12]. Великий відсоток уражених туш, контамінованих бактеріями групи Enterobacteriaceae, що надходить для реалізації на агропродовольчі ринки для споживання населенню, є групою ризику (у 96-98 \% випадках) за харчовими отруєннями, викликаними бактеріями роду Escherichia i Proteus [7, 10].

Мета досліджень - проведення оцінки мікробіологічного ризику м'яса свиней, в залежності від ступеня ураження саркоцистозом.

Завдання дослідження:

1. Провести аналіз епідеміологічних даних по звітам Міністерства охорони здоров'я України.

2. Провести дослідження зразків м'яса з різним ступенем ураження саркоцистозом на загальну кількість мікроорганізмів в 1 г (МАФАМ - кількість мезофільних аеробних і факультативно анаеробних мікроорганізмів) згідно 3 ГОСТ 10444.15-94 [4], на патогенні мікроорганізми в т. ч. Salmonella в 25 г (ДСТУ EN 12824:2004) [5], бактерії групи Enterobacteriaceae в 0,1 г (ГОСТ 21237-75) [2] та на дріжджі та цвілеві гриби, 


\section{ВЕТЕРИНАРНА МЕДИЦИНА}

КУО в 1 г згідно з ГОСТ 10444.12-2013 [3].

Матеріали і методи досліджень. Матеріалом для дослідження слугували 380 туш свиней віком 8-14 місяців. 3 цієї кількості виявлено 21 випадок, який мав характерні ураження звапненим та незвапненим саркоцистозом і становить 5,5\% від загальної їх кількості. Інтенсивність інвазії становила 2-16 \% мікроскопічних саркоцист на 1 г м'яса. Проби м'яса як здорових, так i хворих тварин відбирали згідно з ГОСТ 2123775[4], слідуючи діючим правилам проведення бактеріологічного аналізу.

Усього досліджено 25 зразків. М'язову тканину відбирали від згинача передньої і задньої кінцівки. Методологія та алгоритм дій по встановленню оцінки мікробіологічного ризику бактерій, виявлених під час бактеріологічного дослідження м'яса свиней, уражених саркоцистозом, проводили відповідно до загальноприйнятих міжнарод- них вимог 3 використанням наступних чотирьох складових:

1) ідентифікація небезпеки;

2) визначення характеристики небезпеки;

3) оцінка впливу;

4) визначення характеристики ризику.

У процес оцінки мікробіологічного ризику м'яса свиней, уражених саркоцистозом, включено кількісну та якісну інформацію мікробіологічних небезпек в дослідженому матеріалі.

Схема оцінки мікробіологічного ризику забруднення бактеріями м'яса свиней, уражених саркоцистозом, наведена на рисунку.

Оцінку мікробіологічного ризику формували на основі проведених мікробіологічних та епідеміологічних досліджень.

3 метою оцінки епідеміологічних даних нами проаналізована звітність Міністерства охорони здоров'я України (табл. 1).

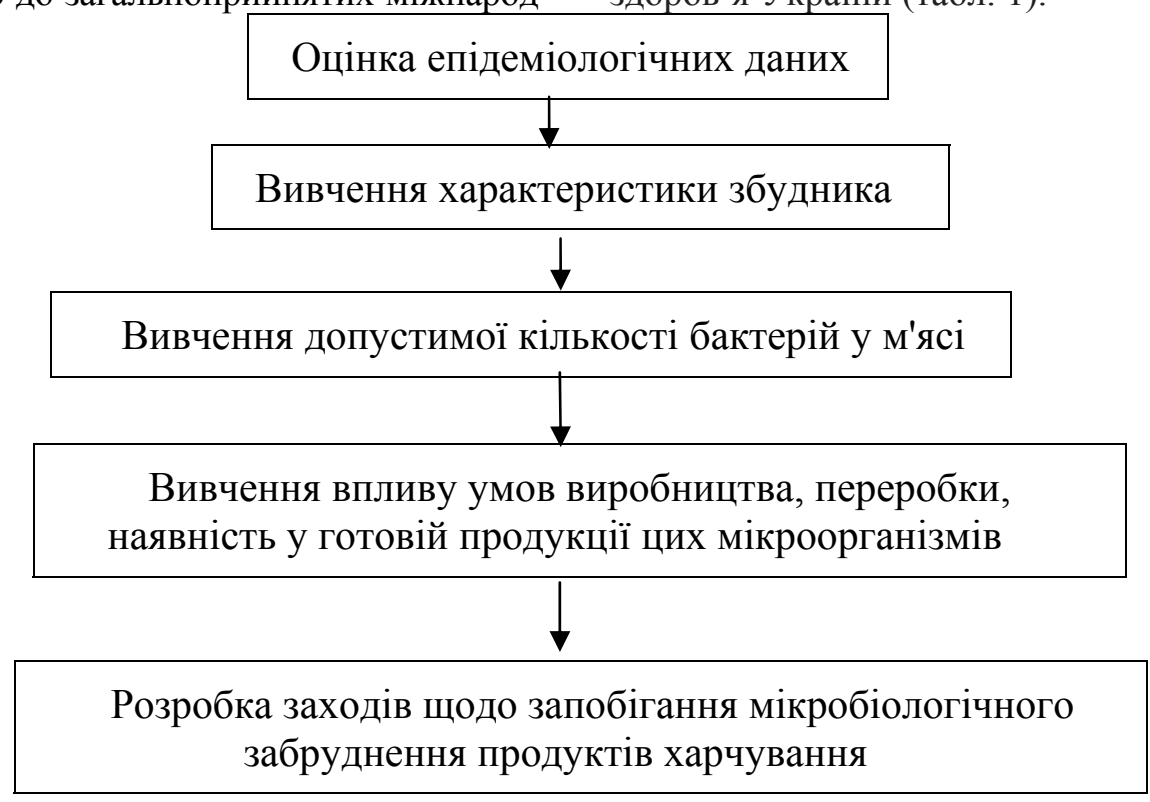

Рис. Схема оцінки мікробіологічного ризику туш свиней, уражених саркоцистозом

1. Спалахи харчових отруєнь та гострих кишкових інфекцій в Украӥні

\begin{tabular}{|c|c|c|c|c|c|c|}
\hline $\begin{array}{c}\text { За даними } \\
\text { МОЗ України }\end{array}$ & $2009 \mathrm{p}$. & $2010 \mathrm{p}$. & $2011 \mathrm{p}$. & $2012 \mathrm{p}$. & $2013 \mathrm{p}$. & $2014 \mathrm{p}$. \\
\hline спалахів & 39 & 42 & 40 & 23 & 48 & 68 \\
\hline хворих & 1037 & 717 & 785 & 430 & 822 & 1260 \\
\hline дорослих & 478 & 427 & 339 & 297 & 432 & 820 \\
\hline дітей & 559 & 290 & 446 & 153 & 390 & 440 \\
\hline $\begin{array}{c}\text { випадків захворю- } \\
\text { вання на 100 тисяч } \\
\text { населення }\end{array}$ & 2,25 & 1,55 & 1,7 & 0,93 & 23,61 & 29,81 \\
\hline
\end{tabular}




\section{ВЕТЕРИНАРНА МЕДИЦИНА}

За даними Міністерства охорони здоров'я 3 2009 по 2012 роки кількість хворих на харчові отруєння та гострі кишкові інфекції зменшилася. Якщо в 2009 році було 2,25 випадків на 100 тисяч населення, то в 2010 році цей показник становив 1,55 , в 2011 році - 1,7, а в $2012-0,93$.

За 2013 та 2014 роки кількість хворих на харчові отруєння та гострі кишкові інфекції збільшилась до 23,61-29,81 на 100 тисяч населення, що свідчить про погіршання соціальної та економічної ситуації в країні в цілому.

Результати досліджень. На першому етапі досліджень, метою якого було проведення ідентифікації мікробіологічної небезпеки в м'ясі свиней $з$ урахуванням аналізу бактеріального обсіменіння відібраних проб від здорових і хворих саркоцистозом тварин, було виявлено Escherichia coli, Proteus, Salmonella, Enterobacter, Klebsiella, коринебактерії, ентерококи, дріжджі та плісняві гриби.

На другому етапі досліджень встановлювали якісну та кількісну характеристики небезпеки обсіменіння туш свиней, хворих саркоцистозом.

Кількісна характеристика небезпеки обсіменіння туш визначалася шляхом диференціації серологічних властивостей виділених мікроор- ганізмів. На цьому етапі основна увага приділялася визначенню рівня контамінації свинячих туш (кількісна характеристика небезпеки) бактеріями Escherichia coli, Proteus.

На третьому етапі досліджень вивчали вплив захворювання саркоцистозом на динаміку кількості бактерій у м'ясі (МАФАМ - мезофільні аеробні і факультативно анаеробні мікроорганізми) 3 метою отримання даних для розробки способу прогнозування кількості цих мікроорганізмів.

У хворих тварин у 18 пробах м'яса були виділені Escherichia coli. В семи зразках м'яса свинини в разі саркоцистозу був виділений Proteus (табл. 2).

3 таблиці 2 бачимо, що в м'ясі свиней кількість мезофільних аеробних і факультативно анаеробних мікроорганізмів (МАФАМ) у випадку зараження звапненим саркоцистозом найвища i сягає до 720 колоній $(\mathrm{P}<0,05)$, трохи нижче в разі зараження незвапненим саркоцистозом i становить в середньому $250(\mathrm{P}<0,05)$. У контролях (5 зразків) загальна кількість мікроорганізмів (МАФАМ) була в межах норми $(\mathrm{P}<0,05)$. У 8 зразках м'яса, зараженого незвапненим саркоцистозом висівали бактерії роду Proteus та E. coli в 0,1 г, гриби роду Candida до 34 колоній.

2. МАФАМ м'яса і печінки хворих саркоцистозом свиней, $n-25$

\begin{tabular}{|c|c|c|c|c|}
\hline $\begin{array}{c}\text { Найменування } \\
\text { зразків } \\
\mathrm{n}=25\end{array}$ & $\begin{array}{c}\text { Кількість } \\
\text { мезофільних } \\
\text { аеробних і факульта- } \\
\text { тивно анаеробних } \\
\text { мікроорганізмів } \\
\text { (МАФАМ), } \\
\text { КУО в } 1 \text { г }\end{array}$ & $\begin{array}{c}\text { Патогенні } \\
\text { мікроорганізми } \\
\text { в т.ч. } \\
\text { Salmonella в } 25 \text { г }\end{array}$ & $\begin{array}{c}\text { Бактерії групи } \\
\text { Enterobacteriaceae } \\
\text { в } 0,1 \text { г, } \\
\text { E. coli в } 0,1 \text { г }\end{array}$ & $\begin{array}{c}\text { Дріжджі й цвілеві } \\
\text { гриби, } \\
\text { КУО в } 1 \text { г }\end{array}$ \\
\hline $\begin{array}{c}\text { Контроль (зразків } \\
\mathrm{n}=12)\end{array}$ & $1,7 \times 10^{2}$ & Не виявлено & Не виявлено & $2,0 \times 10^{1}$ \\
\hline $\begin{array}{c}\text { М'ясо свиней } \\
\text { уражених звап- } \\
\text { неним саркоцис- } \\
\text { тозом } \\
\text { (зразків } n=12 \text { ) }\end{array}$ & $7,2 \times 10^{3}$ & Не виявлено & $\begin{array}{c}\text { E. coli } \\
\text { Proteus } \\
\text { Corynebacterium } \\
\text { Enterobacter } \\
\text { Klebsiella } \\
\text { Enterococcus }\end{array}$ & $6,2 \times 10^{2}$ \\
\hline $\begin{array}{c}\text { М'ясо свиней } \\
\text { уражених незвап- } \\
\text { неним саркоцис- } \\
\text { тозом } \\
\text { (зразків } \mathrm{n}=8)\end{array}$ & $2,5 \times 10^{3}$ & Не виявлено & $\begin{array}{l}\text { E. coli } \\
\text { Proteus }\end{array}$ & $3,4 \times 10^{2}$ \\
\hline Вимоги НД & $1 \times 10^{3}$ & Не допускаються & Не допускаються & Не нормуються \\
\hline
\end{tabular}




\section{ВЕТЕРИНАРНА МЕДИЦИНА}

Під час дослідження 12 зразків м'яса, зараженого звапненим саркоцистозом, висівали бактерії роду Proteus, Corynebacterium, Enterobacter, Klebsiella, Enterococcus та E. coli в 0,1 г, гриби роду Candida до 62 колоній. У контролі бактерії групи Enterobacteriaceae в 0,1 г не виявлено, гриби роду Candida висівали поодинокі колонії.

\section{Висновки:}

1. Зі звапненням саркоцист підвищується кількість мезофільних аеробних i факультативно анаеробних мікроорганізмів (МАФАМ) у м'ясі.

2. Наявність звапненого та незвапненого саркоцистозу у тушах підвищує ймовірність обсіменіння бактеріями групи кишкової палички,

\section{БІБЛІОГРАФІЯ}

1. Деркач I. М. Аналіз біологічних ризиків в основі забезпечення епізоотичного благополуччя та безпечності харчових продуктів в Україні / I. М. Деркач // Ветеринарна медицина України. №7. - 2013. - С. 25-28.

2. ГОСТ 21237-75 Мясо. Методы бактериологического анализа. - М., 2006. (Действителен от 1.01.1977). - (Межгосударственный стандарт).

3. ГОСТ 10444.12-2013 Методы выявления и подсчета количества дрожжей и плесневых грибов. - М., 2014. - (Действителен от 1.07.2015). (Межгосударственный стандарт).

4. ГОСТ 10444.15-94 Продукты пищевые. Методы определения количества мезофильных аэробных и факультативно-анаэробных микроорганизмов. - М., 2010. - (Действителен от 1.01.1996). (Межгосударственный стандарт).

5. ДСТУ ЕN 12824:2004 Мікробіологія харчових продуктів і кормів для тварин. Горизонтальний метод виявлення Salmonella (EN 12824:1997, IDT). - (Чинний від 1.07.2005). - (Держспоживстандарт України).

6. Сфімова О. М. Аналіз мікробіологічної без-
Proteus, Corynebacterium, Enterobacter, Klebsiella та ентерококами.

3. Кількість дріжджів у зразках м'яса, заражених саркоцистозом у порівнянні 3 контролем більше до 30 раз.

Перспективи подальших досліджень. Ризики захворювання зараженої саркоцистозом свинини очевидні, їх необхідно контролювати i управляти ними. Це вказує на необхідність проведення постійного мікробіологічного контролю на всіх етапах та запровадження цілеспрямованих профілактичних заходів щодо запобігання зараженню саркоцистами та бактеріальній контамінації сировини і готового продукту.

печності національної продукції тваринного походження, призначеної для експорту / О. М. Єфімова, В. В. Касянчук // Ветеринарна медицина України. - №1. - 2014. - С. 30-34.

7. Протейная инфекция / [Лукач И. Г., Биденко С. И. и др.]. - К. : Здоровье, 1985. - С. 9-12.

8. Про безпечність і якість харчових продуктів. Закон України від 23 грудня 1997 р. [зі змін. та доп.] внесеними Законами України, від 13 вересня 2001 р. № 2681-III, від 24 жовтня 2002 р. № 191-IV.

9. Про ветеринарну медицину. Закон України № 2775-III від 15 листопада 2001 p.

10. Сухарев Ю. С. Энтеротоксины Escherichia coli / Ю. С. Сухарев. - М. : Коллегиум, 2011. $91 \mathrm{c}$.

11. Akshatayeva Z.B. Legal regulation of agriculture in Kazakhstan: Problems and prospects./ Z. B. Akshatayeva, M. A. Elikbay, G. R. Rakhmetova // Life Science Journal Volume 11, Issue SPEC. ISSUE 5, 2014. - Article number 37. - P. 192-198.

12. Mense $M$. Journal of Parasitology / M. Mense, I. P. Dubey. - 2005. - №1. - P. 187-190. 